\title{
GANGRENE IN AN INFANT ASSOCIATED WITH TEMPORARY DIABETES
}

\author{
BY \\ R. D. LAWRENCE, M.A., M.D., M.R.C.P., \\ and \\ R. A. MoCANCE, M.A., M.D., M.R.C.P., Ph.D. \\ (From King's College Hospital, London.)
}

Gangrene and diabetes are both extremely rare in the first few weeks of life. Still more unusual are the cure of the gangrene and the complete disappearance of the diabetes. We propose in this paper first to place on record and discuss such a case, and secondly to review the recorded cases of diabetes in children under one year of age.

\section{Report of authors' case.}

The clinical record of our case is as follows :-

A female infant of 18 days was admitted to King's College Hospital on 12th March, 1931, under Dr. Still. Four bluish-black patches were present in different parts of the skin and the child was obviously extremely ill.

She was the first child of healthy parents, born at full time after a normal labour in which instruments were used. Her birth weight was $7 \mathrm{lb}$. $14 \mathrm{oz}$. She was breast fed every three hours, but took rather little milk. The stools were somewhat more green than normal, but the child seemed to be perfectly well and, when the nurse left at the 12th day, had regained exactly her birth weight.

On the 15th day a black patch was noticed on the flexor aspect of the right wrist, and that night and the next the child slept poorly and was disinclined for food, but seemed otherwise well. On the 17th evening a black mark was seen on the dorsum of the left ankle, and next day two other blue patches were noticed, one extensive on the right hip. The child was brought to hospital and admitted in the early evening.

On admission her temperature was $96 \cdot 8^{\circ}$, pulse 160 , and respirations 44 per minute. The child looked wasted, the skin was loose and inelastic, the weight only $5 \mathrm{lb}$. 7 oz., so that a rapid loss had taken place in a few days. On the right hip, just orer the trochanter, was a large round purple-black patch (5 by $4.5 \mathrm{~cm}$.) with a dark red margin, neither raised nor very indurated. There were smaller similar oblong patches on the right wrist and left ankle. Nothing abnormal was found on general examination elsewhere, although the child was evidently extremely ill.

The child was fed every $2 \frac{1}{2}$ hours on Nestlé's milk ( 1 part in 10 water) with lactose added, so that the diet contained 18-20 grm. carbohydrate per day. Brandy, 2 minims, was added to alternate feeds. 
13th March. A fresh blue patch (2 by $2 \mathrm{~cm}$.) appeared on the other hip just orer the trochanter. It was clear that the gangrenous area over each trochanter had dereloped at pressure points, and the black areas on the wrist and ankle were probably also subjected to pressure as the child lar with its limbs folded orer each other. Temperature was 98-99:, pulse 160 and respirations 44 per minute. The child seemed desperately ill although she took her feeds. The brandy was omitted and sherry whey given as alternate feeds to the Nestlés

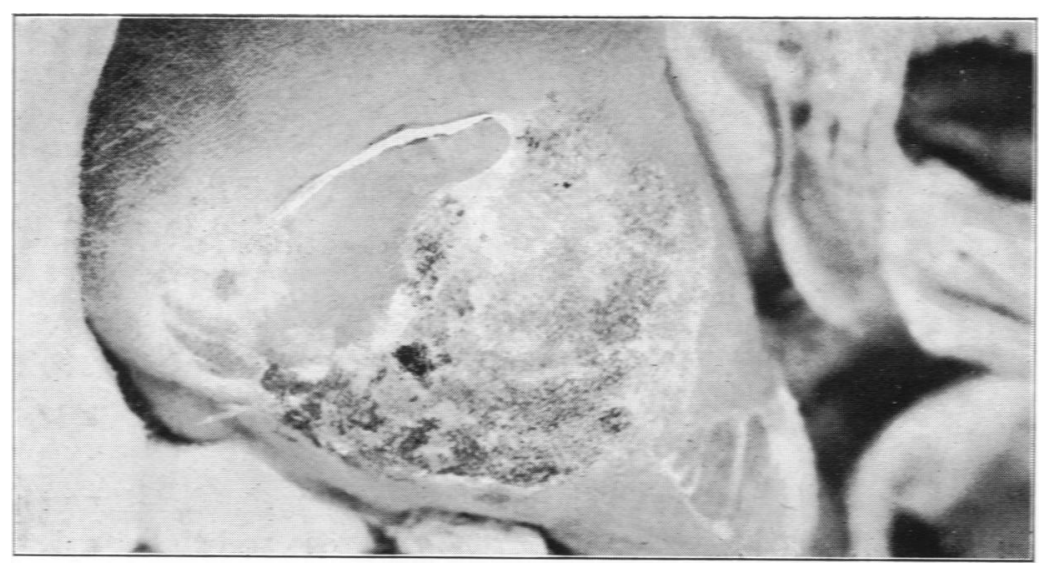

Fig. 1. 2ifth March. Ciangrenous area just breaking down.

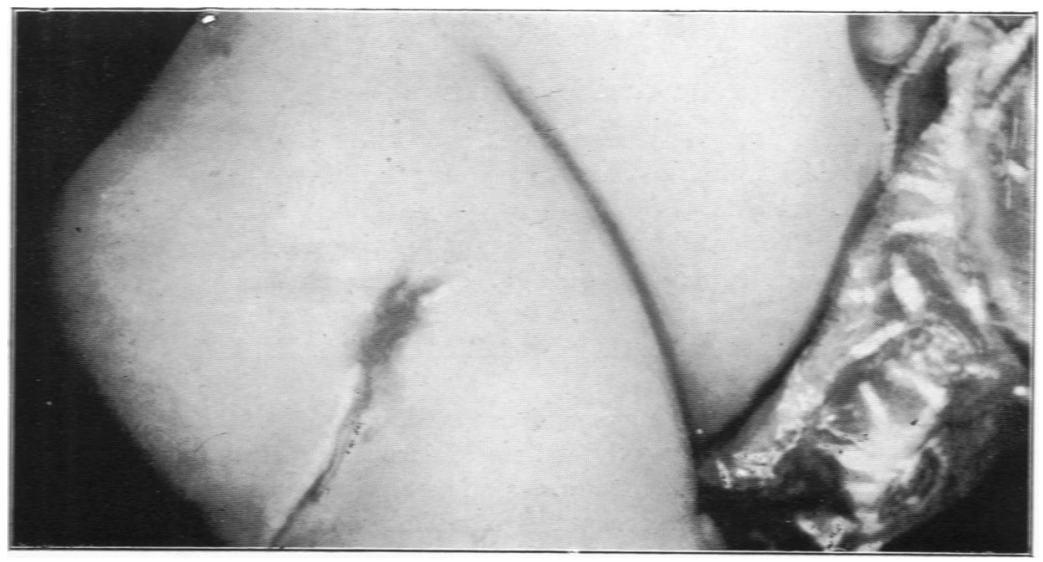

FiG. 2. 16th July. Gangrenous area completely healed for 6 wee's. Note the increased fatness.

mixture. The stools were dark with undigested curd. No diagnosis was made, but 10 c.cm. of polyvalent antistreptococcal serum were given.

Late that night the first specimen of urine was obtained and found to be loaded with sugar, but to contain no acetone bodies.

14th March. The urine from the preceding night was found to contain 12 per cent. of 
sugar, no ketone bodies, but on boiling a heary cloud of albumin. Microscopically a few leucocytes, but no red blood corpuscles or casts were detected. The blood-sugar was approximately 0.6 per cent. As these tests demonstrated diabetes, insulin, 1 unit every 4 hours. was commenced and the same diet continued. The child seemed much weaker with a pulse of 166 (approximately) and a temperature of $100^{\circ} \mathrm{F}$.

15th March. Qualitatively the urine contained less. but still considerable amounts of sugar. On account of the gangrenous areas, it was considered inadrisable to hold the child orer a ressel to obtain specimens and it was extremely difficult to collect more than a few drops of urine to test for sugar. One unit of insulin was continued four-hourly and the same feeding. The general condition seemed desperate. The temperature rose to 103 , the pulse rate remained about 160 , but the respirations at times rose to 80 per minute. Frequent jerking nystagmoid movements of the eves to the right were observed. but the fundi appeared normal. The patches on both hips were now definitely gangrenous, of a dull dark slate colour with red inflammatory edges, the whole area feeling brawny.

16th March. The urine still contained a large amount of albumin but only a trace of sugar (about 0.2 per cent.), and a few white blood corpuscles and granular casts with many oxalate crystals were observed in the deposit. Insulin was reduced to half a unit four-hourly. The babr's respirations were steadier and the nystagmoid morements less obrious. The child was so weak that it had to be fed by a pipette every hour.

17th March. The sugar in the urine was reduced to the merest traces and accordingly insulin was reduced to $\frac{1}{2}$-unit morning and erening. The child was extremely feeble. but no further extension of the gangrenous areas had taken place.

18th March. As the reducing substance in the urine still amounted to only the merest trace, $\frac{1}{2}$-unit of insulin was given in the morning. This was the last dose the child received. It was thought that the slight trace of 'glycosuria' might be lactose, which was being added to the feeds. Sufficient urine to test this was never obtained. As no more than traces of 'sugar appeared subsequently in the urine. further insulin was deemed unnecessary.

19-28th March. The temperature gradually fell from $103^{\circ}$ to $100^{\circ}$ in this period, and the child slowly improved and gained $5 \mathrm{oz}$. The gangrenous areas on both hips siowly separated and weak wet eusol dressings were substituted for powder. The last trace of reducing substance disappeared from the urine on the 2lst March and nerer appeared again. Minute traces of protein were excreted for another fortnight. The diet was changed to a Cow and Gate milk feed suitable for a normal child of its age.

Normal diet was continued and at the end of May the child was discharged apparently normal in every respect and gaining $4 \mathrm{oz}$. a week. A dose of glucose ( $1 \frac{1}{2} \mathrm{grm}$. per $\mathrm{kgrm}$. of weight) was substituted for an ordinary feed and no glycosuria resulted. By the end of June the largest gangrenous area had completely healed. the urine was entirely normal, and the blood-sugar concentration 1 hour after a feed was $0-058$ per cent., a low normal figure.

Figures 1 and 2 are from photographs of the largest gangrenous area before and after healing.

ScyMary. - An infant who had previously made normal progress dereloped four black skin areas, two frankly gangrenous, between the 15th and 18th days after birth. At the same time an acute and serere form of diabetes dereloped and no general infection or disease of the central nerrous system was discorered to account for the hyperglycæmia. The diabetes responded to insulin treatment. rapidly disappeared, and remained absent when the insulin was discontinued. The gangrene healed slowly in 11 weeks. The child was discharged from hospital normal in every way.

\section{Case records of infantile diabetes.}

Cases of diabetes in infants under twelve months are very rare and the recorded cases have never been collected or discussed in the British literature. In $1913 \mathrm{Knox}^{\circ}{ }^{\circ}$ searched the medical records from 18.52 to 1913 and published 
in America 16 cases (including one of his own) which appeared to him to be examples of true diabetes mellitus. He dismissed 11 others which had been reported as diabetic, because the eridence was not conclusire. Since then no complete collection of cases has been made in the literature of any country.

Within the last decade our knowledge of diabetes has been extended and the criteria of diagnosis hare become more exacting. Besides glycosuria, hyperglycæmia and ketonuria (whether absent or present) are now considered essential details of any records of adult diabetes. These are still frequently unarailable or omitted in records of infantile diabetes, and the diagnosis often rests on symptomatology and the presence of glycosuria. These latter, if rery definite, may be accepted as clearly establishing the diagnosis, especially if the usual fatal issue is recorded and no other cause of death is found.

In cur critical review of the literature we hare accepted infantile diabetes as proven in cases :-

1. Where definite wasting, thirst, polyuria and preferably ketonuria were present, accompanied by a heary glycosuria (over 2 per cent.), whether the reducing substance was actually proved to be glucose or not, eren if hyperglycæmia was not established; or

2. Where, if the symptoms and glycosuria were slight, definite and recurrent hyperglycæmia (over $0 \cdot 2$ per cent.) was established.

We hare classed as non-diabetic :-

1. Cases which show only one or two symptoms suggestive of diabetes, in which the glrcosuria was only slight and might be due either to lactosuria (not infrequent in infants) or to renal glycosuria, a low renal threshold, which is as common in children as in adults in our experience ; and

2. Cases in Group 2 above in which hyperglycæmia is present, but in which it is nerer excessive (i.e., under 0.3 per cent.), and which may be explained by temporary infection or disease of the central nerrous system, such as trauma, tuberculous meningitis or hydrocephalus (Harrison ${ }^{13}$ ).

Adopting the above criteria, we give a short description of all the cases so far recorded arranged in chronological order. Some doubtful cases are mentioned: these not described fully and are marked with an asterisk. General features are discussed later.

Haūner ${ }^{14}(1850)$ reported the first authentic case in an infant of 11 months. The child became thin and thirsty and passed 7 to 9 litres of 'sweet urine' per day. It died in coma one month later.

Kitselle ${ }^{19}$ (1852) recorded another case soon after. A male child (his own son) plump and strong at birth, dereloped a few dars later srmptoms of diabetes. 'Honered' napkins were first noted, then polyuria with sugar was found on the 14 th day. The child was restless, thirsty, hungry, and dry skin and extreme emaciation dereloped. It surrived for 6 months, a living skeleton, being fed on breast milk, bread and water and semmel tea. The urinary tract then became infected and the child died. No mention is made of hereditary or causal factors.

Rosbach $^{34}(1874)$ described a female child of 7 months, previously healths, who had a serere fall on the head, followed by conrulsions and unconsciousness. A month later thirst, polruria. furunculosis and wasting became obrious. The glycosuria raried from 2 to 10 per cent. and, although feeding with broths, cream and diluted milk diminished the sugar, she died in extreme 
emaciation 3 months after the accident. No family history is recorded and, although a postmortem examination was made, the pancreas was not examined. This is not surprising as the connection between the pancreas and diabetes was only discovered in 1889.

Busch' $(\mathbf{1 8 7 6 )}$ records a case ' under a year' who became restless, thin, and very thirsty. A glycosuria of 5 per cent. was discovered, and the child died in coma 23 days later.

Hagenbach ${ }^{12}(1879)$ reports the case of a male infant who developed thirst and polyuria at 8 months. At 10 months a heary glycosuria was found and hydrocephalus noticed. He was fed with milk, dosed with salicrlic acid, and died 11 months later. At autopsy gangrene of lungs, tuberculous pleurisy on the right side, and odema of the pia mater with chronic internal hydrocephalus were found.

*Garnerus ${ }^{11}$ (1884) published the case of a male child entitled, ' Cure of Diabetes Mellitus and Insipidus in an Infant.' Polyuria (sp. gr. 1008-10) was noted almost from birth and some sugar (? glucose) found at the 2nd month. The sugar disappeared later, but polyuria (sp. gr. 1000) remained. We do not consider even temporary diabetes proven in this case.

Nichues $^{31}$ (1891) records that a male infant of 3 months, whose grandfather died of diabetes, developed abscesses and polyuria. 3 per cent. of sugar was found in the urine and the child soon died.

Tavaria $^{37}$ (1893) reports a case of a Parsee child (sex unstated) who, previously in perfect health, fell out of its cradle at 10 months, but sustained no visible injuries. It became restless, and developed a fever of $103^{\circ}$, for which no cause was found. It passed urine 2-3 times per hour, was very thirsty and crowds of flies were noticed round the napkins. A large amount of sugar was found (' about one-third'), and the child became very weak, but not emaciated. Two weeks later it developed pneumonia and died in coma. The author blames a ' nervous cause' as responsible.

Bell $^{5}$ (1896) was called to attend a well-nourished male child of 3 months, who had dereloped thirst and genital irritation one month before. He found much sugar in the urine and eczema of the thighs. Nutrition was good and constipation absent. The baby was fed on its mother's milk (she being put on a diabetic diet!) and given unlimited skimmed milk and water for its excessive thirst. It died in coma 4 days later and the post-mortem examination showed nothing abnormal macroscopically. The father's aunt had died of diabetes.

* Baumel* (1900) reports that a female infant with no diabetic family history developed at 6 months odema, itching, hunger and polyuria (' urine like water,' sp. gr. not stated). Traces of 'sugar,' never more than $0 \cdot 150$ per cent. were found in the urine, but the reducing substance was never proved to be glucose. The child continued breast feeding, received a few medicaments (including extract of lily of the valley !) and the cedema and glycosuria disappeared in 6 weeks. Whether the polyuria and thirst disappeared simultaneously is not mentioned. To our mind no proof of diabetes mellitus is given in these records.

Orloff $^{32}$ (1901) records a case of a male of 5 months who developed restlessness, thirst, polyuria, boils and a sacral sore. Glucose was found in his urine and the polyuria was excessive. He wasted rapidly and died in a few days. Hydrocephalus, especially of the lateral ventricles, was found and also bronchopneumonia and acute enteritis.

Young 30 (1902) describes a male foundling of 6 months whose illness began with romiting, dryness of the skin, emaciation, enlarged kidneys and liver. 5 per cent. of sugar, albumin, and a few casts were found in the urine. He was given pasteurized milk and codein which had no effect. He lived one month and died of pneumonia. Post-mortem the kidneys were twice the normal size, the cortex indurated, the parenchyma inflamed and also the mucous membrane of the bladder. The liver also was enlarged, but nothing else abnormal was discovered.

Langstein's (1909) describes three cases :-

*1. A six months' child with severe chronic hydrocephalus developed a glycosuria varying from $0 \cdot 1$ to 1 per cent., irrespective of diet, but showed no symptoms of diabetes. At death extreme hydrocephalus and thinning of brain were confirmed.

*2. An anencephalic child showed $0 \cdot 5-1$ per cent. of sugar in the urine from the 7 th to loth day, when it died. It had no diabetic symptoms. 
3. A male child of 8 months dereloped symptoms of diabetes, dry skin, thirst, hunger, loss of weight. There was no family history of diabetes, but the child had been orerfed from the sixth month with large excess of sugar and milk, receiring about 200 grm. carbohydrate per day. He was put on a milk mixture containing 40 grm. carbohydrate and excreted $10-6$ per cent. of sugar, but no acetone (total excretion not stated). He was then fed on a 'sugar-free' milk containing only $8 \mathrm{grm}$. carbohydrate, and excreted $8 \mathrm{grm}$. of glucose per day. On this diet a heary ketosis and early signs of coma appeared which cleared up with sodium bicarbonate and two 'oatmeal days.' Later the diet consisted of 'sugar-free' milk, whey, some oatmeal and broth and spinach (quantities not stated) on which the glycosuria disappeared. When this diet was increased, sugar reappeared in the urine. On this restricted diet the weight and clinical condition remained stationary for some months, but the ultimate fate of the child is not mentioned.

Lauritzen $^{25}$ (1910) mentions a boy of 8 months with large amounts of sugar and ketone bodies in his urine who died in coma 3 months later.

Eaton and Woods' (1911) describe their case in a healthy breast-fed baby weighing $16 \frac{1}{2} \mathrm{lb}$. at 6 months. The parents were normal, but one grandmother had died of diabetes. Delivery was instrumental and the babs suffered a large superficial cut orer the left eye, but the head seemed normal later and the baby made excellent progress until the 6 th month. Then one toe became red and swollen and a resicle dereloped on it and a week later a toe of the other foot became the same. Next thirst, wasting and sticky napkins were noticed, and 6-10 per cent. of sugar and 'acetone but no diacetic acid' were found in the urine. The baby was fed on breast milk and giren ' trypsogen" which was not found beneficial ; later washed cream and beef-juice were given. Glycosuria was always present, but Knox states that the child lired for two years longer.

*Cuno: (1911). A 15 day old marasmic child (weight 2,800 grm.) was found to hare $0 \cdot 3$ per cent. glycosuria. It died in a week from bronchopneumonia and post mortem had an abnormally small pancreas ( $1 \cdot 5 \mathrm{grm}$.) showing cirrhotic changes which he considered congenital. Not a clear case of diabetes.

Knox $^{20}$ (1913) describes his case in an 8 months' female child in considerable detail. There was no family history of diabetes and the babs was fairly healthy till $5 \frac{1}{2}$ months and the urine was known to be sugar free, as it had been examined occasionally for previous slight pruria. After some slight digestive upset, she receired for a time a large amount of malt soup (10 per cent.) in her milk. This was stopped and the child did well for another month, when loss of weight, dry skin and a fruity odour in the breath led to the discorery of 5 per cent. of glucose and some acetone in the urine. Slight ferer $\left(99-100^{\circ}\right)$ was present for a few dars. 'Eiweiss milk-cream' mixture was giren, whereupon the glycosuria diminished to 1.5 and later to 0.6 per cent., but in about a week drowsiness, nausea and air hunger dereloped and, in spite of treatment by bicarbonate and fluids, she died in coma with a rising temperature and bronchopneumonia. The post-mortem reports on the pancreas are giren later.

Kochmann ${ }^{21}$ (1922) described the first child (birth weight 2,500 grm.) of healthy parents who at $4 \frac{1}{2}$ months became rery thin and tired and dereloped intertrigo. Sugar ( $5-9$ per cent.) was found in the urine, but no acetone. On reduced diet the sugar fell to $1-2$ per cent. At that time the blood sugar fasting was 0.095 , but rose after food to 0.387 per cent. Just before death the fasting blood sugar was 0.144 per cent. This is the first case of infantile diabetes in which determinations of blood sugar were made. On special diet there were only traces of sugar in the urine. When taking the a rerage amount of milk for its age, the child put on weight, but excreted more sugar. An oatmeal ' cure ' had also this effect. At $6 \frac{1}{2}$ months it dereloped ferer and died in coma from confluent hæmorrhagic bronchopneumonia. The autopsy is described later.

Ashbr ${ }^{3}$ (1923). A child of 5 months dereloped slight prelitis and ferer. The urine does not seem to hare been tested for sugar at this time, but soon gangrene of two toes dereloped and then glycosuria was found. The child died some weeks later and was almost comatose 3 days before death.

Yajor and Curran 28 (1915) describe the case of a male child of 11 months, who was admitted to hospital for glycosuria of 1 month's duration. The blood sugar varied between 0.094 and 0.2.2.2 
per cent. I family history of diabetes was negative. A diet of whole milk, regetables and cod liver oil was giren and insulin 6-10 units per day. Cataracts had already dereloped in both lenses, which were extracted and found not to be congenital. One year later the insulin was stopped, but glycosuria returned. 2 to 3 units a day were found necessary. We do not know the further history, but presumably the child's condition required the continued use of insulin.

Schippers ${ }^{35}$ (1925). A girl of 8 months old, the 3rd child of healthy parents, dereloped a temperature of $102^{\circ} ; 9 \cdot 1$ pel cent. of sugar and much acetone were found in the urine as well as protein, casts and white blood corpuscles. Insulin, 5 units, b.d., was giren. The temperature became normal in 5 days and the casts disappeared. A typical day's food consisted of milk 200 grm., cream 50 grm., butter 3.7 grm., potato 100 grm., regetable 100 grm., apple 150 grm. (= $46 \mathrm{grm}$. carbohydrate, $17 \mathrm{grm}$. protein and $54 \mathrm{grm}$. fat). She progressed for many months on 8 or 9 units of insulin b.d. Suddenly at the age of 2 years 2 months she became ill, romited and could not be fed. Insulin and carbohỵdrate were giren as much as possible, but she died in coma 2 days later.

De Lange ${ }^{8}$ reports the autops on this case which we shall deal with later.

Arndt and Welcher'(1926) describe a case of considerable interest in a child of 3 months with no diabetic heredity. It weighed 2,000 grm. at birth and gained on the breast for 4 weeks, although passing 4 or 5 loose motions a das. At 10 weeks it seemed weak and tired and on admission to hospital was pale and rery poorly nourished, with œdema of the evelids and orer the tibiæ. The physical examination rerealed nothing else abnormal. The urine was strongly positive to Trommer's test, but otherwise normal. The blood count showed a secondary anæmia ; red blood corpuscles, $2,570,000$ per c.mm., Hb. 58 per cent. The child took its food well (8-900 grm. of mother s milk) and the weight and œdema remained constant. The urine (sp. gr. 1,005) contained 0.8 to 1 per cent. glucose, but no acetone; and the motions, $4-6$ a day, were loose, clear gold colour, contained mucus, but were not 'shins'. The fasting blood sugar was . $\mathbf{2 5} \overline{7}$, and 1 and 2 hours after food it was $\cdot 275$ and $\cdot 299$ per cent. respectirely, clearly diabetic. No symptoms of diabetes were present. The Wassermann test was negative. No change occurred during $\bar{\tau}$ dars in the clinic until 4 units of insulin were giren. No definite signs of hypoglycæmia were obserred, but 10 hours later the oedema increased and death occurred from heart failure.

The autopsy (details given later)showed much greater defect in the alreolar than islet tissue, and we presume that this as well as the diabetes contributed to the marasmus.

Ramser $^{-33}$ (1927) describes the case of a full term male, delirered naturally, who had a family history of diabetes, but 5 brothers and sisters alive and well. The birth weight was 2,200 grm., at 18 dars 2,200 grm., and at 4 weeks 2,085 grm. Then the child dereloped slight fever, catarrh of the upper respiratory tract, polydipsia, polyphagia and polyuria, and was found to have a heary glycosuria. In hospit.l he lost ground on breast milk and protein milk (140 cal. per kgrm.) and $\frac{1}{2}$-unit of insulin (? how often) made him sugar-free on the 4 th day. The insulin was discontinued twice. but on each occasion sugar reappeared in the urine. The blood sugar was $0 \cdot 2 \cdot 25$ per cent. but the time relation of this test to food is not stated. Finally, after 18 days insulin he kept sugar-free on whole lactic milk. When syrup was added, sugar returned with a blood sugar of 0.263. which fell to $0 \cdot 750$ per cent. on omission of the syrup. He was discharged from hospital in 6 weeks on $600 \mathrm{c} . \mathrm{cm}$. whole acid milk ( $120 \mathrm{cal}$. per kgrm.) and remained sugar-free except when syrup was given experimentally 3 and 6 weeks later. At 7 months he was in excellent health(wt. $=7,900$ grm.), and the urine was sugar-free on a diet of whole milk, cream of wheat, regetables, orange juice and cod liver oil-practically normal.

Br the courtesy of Dr. F. G. Hedenstrom, of St. Paul, Minnesota, we are able to give details of the child at 4 years of age. A blood-sugar curre with glucose (amount not stated) gare the following completely normal results :-

$\begin{array}{ccccccc}\text { Fasting } \ldots & \ldots & \ldots & \ldots & \ldots & 0.060 & \text { per cent. } \\ \text { After l hour } & \ldots & \ldots & \ldots & \ldots & 0.095 & , \\ , \quad 2 \text { hours } & \ldots & \ldots & \ldots & \ldots & 0.082 & , \\ , \quad 3,, & \ldots & \ldots & \ldots & \ldots & 0.077 & , \\ , \quad \mathbf{4}, & \ldots & \ldots & \ldots & \ldots & 0.074 & ,\end{array}$


We gather that the child is perfectly well on a normal diet. Dr. Hedenstrom particularly states that polyphagia and polydipsia were present before the initial catarrh, so that the diabetes was not caused, but only accentuated, br this infection. In this case the presence of true diabetes with subsequent recovery is clearly established.

Lenstrup=6 (1928) mentions a child of 11 months doing well on insulin, but gives no details.

Yorton 20 (1928) reports the case of a male child of 12 months whose paternal grandfather had diabetic gangrene. The infant had gained rapidly till the 12th month, when it became fretful, lost weight and developed hunger, thirst and polyuria. The urine was loaded with sugar and diacetic acid. It was given 12 units of insulin, b.d., with a diet equivalent to 74 grm. glucose and 62 grm. fatty acids, and soon developed symptoms of insulin overdosage. A month later 6 units of insulin, b.d., controlled the diabetes on a diet of $28 \mathrm{grm}$. carbohydrate, $27 \mathrm{grm}$. protein and $56 \mathrm{grm}$. fat. At 2 years the child weighed $25 \mathrm{lb}$. and less insulin was needed to keep it well and practically aglycosuric.

Joslin ${ }^{17}$ (1928) describes a male infant, with a family history of diabetes, who dereloped diabetes at 8 months. He was fed on a nearly normal diet varying from 73 grm. carbohydrate at 10 months to $100 \mathrm{grm}$. at 2 years, supplying about 100 calories per $\mathrm{kgrm}$. In these two years the insulin increased from 12 to 18 units a day, given in three doses, and the urine remained sugar-free. The child kept well and its weight, although subnormal, increased satisfactorily.

Litchfield 27 (1930). A male child, 5 months old, dereloped a napkin rash shortly after its breast feeding was supplemented by cane sugar and cereals. Its birth and early months had been normal and there was no history of diabetes in the family. At $7 \frac{1}{2}$ months $6 \cdot 6$ per cent. of sugar was found in the urine which was reduced to $4 \cdot 3$ on breast feeding alone. Slight ketonuria was present, the blood sugar was 0.420 per cent. and insulin (15-10-15 units) was started. Hypoglycæmia developed and recurred on 10 units b.d. When insulin was stopped the rash and 6.8 per cent. of urinary sugar recurred. Finally the child was given 5 and 7 units per day and kept in excellent condition.

Shelley ${ }^{36}$ (1931) reports the case of a child who was perfectly well till the 8th month. Labour was normal and a family history of diabetes absent. At the 8 th month ' chill and fever' occurred for a few days and again for 4 days during the 9th month. At the 10th month polydipsia, polyuria and irritation of the skin developed, the napkins were noticed to be sticky and at the 11 th month 2 per cent. of sugar and traces of acetone were found in the urine. The blood sugar was $259 \mathrm{mgrm}$. per $100 \mathrm{c.cm}$. The Wassermann and Pirquet tests were negative. A normal diet and 3 units of insulin, t.d.s., were given and the blood sugar is recorded as 327 mgrm., the urine sugar 1 per cent.; 5 units t.d.s. made the urine sugar-free for a few days, but the tlood sugar varied between 240 and $280 \mathrm{mgrm}$. per $100 \mathrm{c.cm}$. evidence of a high renal threshold. After 10 days the child went home and continued to improve on diet and insulin : but polyuria, polydipsia and polyphagia were always worse when insulin was omitted. At 15 months it developed acute fever with diarrhcea and vomiting, epidemic at that time. It died in two days, and an autopsy was not obtained.

\section{Congenital diabetes.}

In only two of the above cases is there any probability that the child was born a diabetic. Three other cases are recorded as congenital diabetes and will now be considered.

Ambard et al. ${ }^{1}$ (1925) describe the case of a child born of a diabetic mother at the $8 \frac{1}{2}$ month of intra-uterine life. The mother was precomatose and was treated with large doses of insulin (up to 180 units a day). On the day when labour was induced the maternal blood sugar was 0-44 per cent.. but had fallen to 0-180 next day when the mother died (blood urea-0.163 per cent.). At birth the sugar in the umbilical cord blood (? artery or vein) was $0 \cdot 242$ and in the placental blood 0.228 per cent. The infant lived only 21 hours and the urine collected from the 11-15th hours contained 1.2 per cent. of sugar, the presence of ketone bodies not being mentioned. Autopsy showed abnormalities (cloudy and hydropic degeneration) of the maternal 
islets, but normal islets in the infant. although the acinar tissue looked cirrhosed and inflitrated with lymphocrtes.

The authors claim that the infant was diabetic, but we consider this not proven. It did not live long enough to disprore the possibility that its hyperglycæmia and glycosuria were due entirely to the maternal diabetes.

Feldman ${ }^{10}(1928)$ reports as congenital diabetes a still more doubtful case. A woman of 32, in the ninth month of her pregnancy, was admitted to hospital after one das of unconsciousness, and died 2 hours later from heart failure. Post mortem, sugar and ketone bodies were found in the urine, and histologicalls the islets of Langerhans were diminished in number and size, and their cells showed 'destruction' and cloudr swelling. The urine of the unborn child contained more sugar than that of the mother, but no ketone bodies. Histologically the child's pancreas showed manr enlarged islets, and odema and dropsical swelling of the cells.

In this case diabetes was not prored, eren in the mother, although it is the best explanation of her death and the urinary findings. This would easily explain the fœtal glycosuria and, as we shall see later, little attention can be paid to theories built on the histological appearance of the islets, on which Feldman's arguments rest.

Nerinn! and Schretter ${ }^{30}$ (1930) describe a more interesting case rery completely. The mother was obriously a mild diabetic in whom thirst and neuritis appeared 3 months before her 8th pregnancy. Her glycosuria was readily controlled by diet and the blood sugar records towards the end of pregnancy raried between 157 and 67 mgrm. per 100 c.cm., not clearly diabetic. Howerer, during a febrile attack 10 dars after labour, her blood sugar rose to 324 mgrm. and insulin was required for a few days, so that definite diabetes was present.

The child, born 12 dars after the reckoned time, weighed 4,750 grm. Her prerious children weighed about $6 \mathrm{krgm}$. The following interesting series of blood sugars were obtained at birth ; amniotic fluid 161, maternal renous blood 104, retro-placental blood 89, umbilical rein 87 , and umbilical artery 62 mgrm. per $100 \mathrm{c.cm}$. Obriously th c child was not diabetic at birth, its blood sugar being lower than the mother's. One of us (R. D. L.) has found this relationship present in 4 cases of children of diabetic mothers.

The child lived 29 days and died with marked cranosis, due to congenital heart disease, confirmed at autopsy. Its capillary blood was frequently tested for sugar. At birth, 62; at $5 \frac{1}{2}$ hours, 52 ; 2nd dar, 52 ; 5th, 62 ; 8th. 106 ; 12 th, 95 ; 15 th, 172; 2-2nd, 162 mgrm. The time of these tests in relation to food is not stated. No glycosuria and no symptoms of diabetes were present.

At autops the pancreas was macroscopically normal although perhaps somewhat hearier than the arerage at one month. The islets were more numerous than in controls of the same age and large hypertrophic islets ('Rieseninseln') were much more frequent than usual. The other endocrine glands were normal except for an enlargement of the anterior lobe of the pituitary which was exceptionally rich in eosinophil cells.

The authors conclude from the hypertrophy of the islets and the rising blood sugar that the infant had an 'orerwork diabetes' (überarbeitungsdiabetes) In our opinion the histological picture is the opposite of diabetic and it is possible that the slightly rising blood sugar may hare been produced by the child's circulatory failure, and especially the cyanosis. Asphyxia is known to elerate the blood sugar and might afford an explanation of the only feature in this child suggesting diabetes. Whether chronic cranosis in an infant can elerate the blood sugar we do not know : it is a point which does not seem to hare been inrestigated.

Conclusion.-On the arailable eridence we do not think any case of congenital diabetes proven in medical records. 


\section{Post-mortem reports on the pancreas.}

In only five of the above cases was any histological examination of the pancreas made, and rery little exact information is arailable on the normal appearance of the infantile pancreas with which to compare these records.

In older children, eridence of lesions of the islets is frequently entirely absent and less commonly obtained than in adults. In 22 children Warren ${ }^{38}$ found the histology of the pancreas entirely normal in 12, and readers are referred to his recent book for further detail. The main histological features in the abore cases will now be described.

Heiberg ${ }^{15}$ describes the post-mortem appearances in a child of $1 \frac{1}{4}$ years who had dereloped the disease at about 1 year old and died in coma. The islet cells were mostly normal, the islets themselves were perhaps rather small. Some round-celled infiltration was present in the islets and surrounding interstitial tissue. Heiberg counted the number of islets per $50 \mathrm{c} . \mathrm{mm}$. and found them reduced in number to 58 instead of the normal $200-300$. Such enumeration. however, is generally agreed to be difficult and of little value (see Warren).

Knox $\mathrm{s}^{20}$ case showed a pancreas which was normal macroscopically. 'Sections of the pancreas showed the lobules to be separated from each other by rather broad septa. which consisted principally of very loose connectire tissue. There were many small round cells in the interstitial tissue which in some places seemed to replace the acini. The connectire tissue was increased. The islets were dininished in size and number. In one section none were seen."

Kochmann ' ${ }^{21}$ case showed fatty changes in the acinous cells and there were very few islets. Considerable generalized lymphocytic infiltration was seen. A small cyst was present in the middle lobe of the pituitary.

D: Lange $^{8}$ made a rery careful examination of Schipper's case. Nothing really abnormal was found in the number, size or histological detail of the islets. The liver contained much glycogen.

Arndt and Welcher found a generalized anæmia, a diffasely fatt ${ }^{2}$ liver. but a normal pancreas macroscopically. On section the pancreatic parenchyma (acini) was widely infiltrated with fat. lesving the islets rather conspicuous. The islets were mostly increased in size and normal in appearance, although some small-celled infiltration was present. They state that the number of islets was diminished ( 218 per $50 \mathrm{c.mm}$.). but in comparison with Heiberg's figures this does not seem to us to be true. Certainly the main histological feature was acinous atrophy although, from the blood-sugar results, islet function was also in rolred. A congenital malderelopment of the pancreas seems probable in this case, and the symptomatology due more to failure of external than internal pancreatic function.

Conclusion.-We feel that these reports do not help us to associate failure of insular function with any constant histological picture. The only characteristic appearance regularly noted is a round-celled infiltration which Warren describes as perhaps the only characteristic lesion of the islands in older children. He states that it is 'obriously not a primary lesion,' but suggests a reaction to some toxic substance or to the necrosis of the islet cells produced by orerstrain.

\section{General discussion.}

We may now proceed to a general discussion of our own and other recorded cases.

1. Incidence.-SEx. This would appear to be overwhelmingly male. Of the cases where the sex has been stated 17 hare been male and only 7 female. In $\mathbf{5}$ cases the sex is not mentioned. 
AGE. Of the cases of proved diabetes, 7 have been recorded between the 9 th and 12th months of life, and exactly the same number between the 6th, and 9 th months and between the 3rd and 6th months. Below three months howerer, only 3 cases have been recorded-all in the first few weeks of lifeand of these 2 have recorered. The third which was one of the earliest ever recorded (Kitselle ${ }^{19}$ ) lived for 6 months and might conceivably have recorered under modern methods of treatment. The arailable evidence therefore suggests that, while orer 3 months the disease resembles the adult type, temporary loss of islet function may occur in the rery early days of life.

2. Symptoms and signs.-These do not differ materially from those of older children and adults. The onset and course have almost always been very acute, which is the usual form of diabetes in older children. Restlessness and slight ferer seem more common initial srmptoms than they are in adults, but these are the disturbances which characterize so many childish complaints that little diagnostic significance can be attached to them. Sticky napkins seem to hare attracted the attention in many instances. Genital irritation and napkin rashes are naturally more frequent.

Gangrene and pre gangrenous changes were noted in two other cases besides our own (Ashbr ${ }^{3}$, and Eaton and Woods'). In older children and young adults these signs are practically unknown and in elderly diabetics are essentially due to concomitant arterial degeneration. In infants it must be presumed that the nutritional disturbance of severe diabetes, acute in our case, may produce gangrene apart from arterial disease.

3. Aetiology.-INFLCENce of HeRedity. In 12 cases no mention is made of a family history of diabetes, either positive or negative. Of the remainder 35 per cent. had a family history of diabetes, which is higher than the figures generally giren for diabetes of all ages, but lower than those of the private cases of one of us (R. D. L.). Ton Noorden thought that hereditary influences were less important in children than in adults, but Joslin's cases point to the opposite conclusion. It is probable, therefore, that the hereditary factor in infants is of similar importance to that in adults.

Nerrocs rsfleexces. Falls on the head have preceded the onset of two of the cases (Tararia ${ }^{37}$ and Rosbach ${ }^{34}$ ), and in the one described by Rosbach the association of the injury with the onset is rery striking. Hydrocephalus has been associated with three of the cases reported (and anencephalus with one), although those of Langstein ${ }^{24}$ hardly conform to our criteria of true diabetes. The diabetes. indeed, in these cases is generally mild and a secondary factor in the fatal result.

IXfLCENCE of OVERFEedrig. This appears to have been a contributory factor in a few cases (Langstein 24, Knox ${ }^{20}$ ) where the child has been forced to take large amounts of sugars, starches and malt extracts. Such cases do not appear before the 6th to 9 th month, but it is erident from the number of children who are fed on very similar lines that the orerfeeding can only have been a contributory factor. 
Paxcreatic disease.-Generalized pancreatic inflammation and cirrhosis seem to hare been responsible for two cases (Arndt and Welcher ${ }^{2}$, Cuno ${ }^{7}$ ). Cuno's case was not definitely diabetic, but mild glycosuria was associated with generalized pancreatic cirrhosis, and in the case recorded by Arndt and Welcher the external disorder of the gland was probably the main cause of death.

It is erident that, as in so many cases of adult diabetes, the ætiology of infantile diabetes remains obscure.

4. Treatment and prognosis.-Before the use of insulin, death was the ineritable issue. Few cases survired the diagnosis by more than a very few months. Most lapsed into coma, but a few succumbed to infections, such as pneumonia. Reduction of the carbohydrate of the diet, by modifying the milk and so on, may have reduced the glycosuria, but made no difference to the fatal issue. Many of the cases, howerer, since insulin was introduced have not only lired, but thriren. No doubt the care of such a child is exacting, but good results are assured if the parents and physician are skilled and careful. Milk must and should form the basis of the diet and is relatively much lower in the ratio of carbohydrate (5) to protein $(3 \cdot 5)$ and fat $(3 \cdot 5)$ than the mixed diets of elder children and adults. The easy and rational treatment therefore is to give the infant a normal diet for its age and enough insulin to balance it. Babies are fortunately not upset br insulin injections, and two, or probably three, small doses a dar gire the best results. If complete control is attempted br two larger doses a day hypoglycæmia will probably ensue. As insulin has been arailable for less than 10 years and so far case records are rare, it is not possible to dogmatize on the future of these children; but there is no eridence at present why they should not grow up normally as older diabetic children have done.

RECOVERIEs.-Apart from our own case, only one complete recorery has been recorded (Ramser. ${ }^{33}$ ) in infantile diabetes. Garnerus' ${ }^{11}$ and Baumel's ${ }^{4}$ cases, where recovery was claimed, do not seem to us to hare been proved cases of diabetes. I rery few cases of recorery in older children have been reported (Joslin $\left.{ }^{18}\right)$, but as eridence of hyperglycæmia was not supplied in these cases, one feels somewhat dubious about their true nature. 'Cures' in adult diabetes are also pooriy substantiated, although great improrement in carbohydrate tolerance is common in the early months of treatment. Joslin hardly belieres in the possibility of a genuine and complete recovery of normal carbohydrate tolerance. This makes the question legitimate whether the two reported cases were truly diabetic. We feel that the eridence on this point in Ramsey ${ }^{33}$ case is absolutely definite and, in our own, permits of no other conclusion. Wasting, glycosuria ( $4 \cdot 2$ per cent.) and extreme hyperglycæmia (0.6 per cent.) were all present, and also, as no other cause for the gangrene was discorered. we hare regarded it as secondary to the upset of carbohydrate metabolism. What disorganized the islet function so completely and yet so reversibly must rema in mere conjecture. No infection or intracranial lesion was ever found to account for the hyperglrcæmia. 
La Barre and Hoet hare shown by different experiments that the secretion of insulin is, partially at least, under the control of the ragus nerres, but we have no reason to suppose that any ragal dysfunction was present in this child. Whaterer the cause it was eridently quickly remored.

We conclude that the islet tissue, perhaps because it was quickly protected from overstrain by the exogenous insulin, was able to recorer from its disorganization and resume its function.

\section{Summary.}

1. A case of gangrene associated with acute diabetes mellitus is reported in an infant of 18 days. Treatment with insulin resulted in a cure of the gangrene and complete recorery from the diabetes.

2. The medical literature from 1850 to the present day has been searched for cases of diabetes in infants under one rear of age. Twentr-six true cases, including our own, are described and discussed. In two complete recorery is established.

We are indebted to Dr. G. F. Still for the opportunity to treat and record this case : also to Dr. Snowball, the house phrsician, and Sister Edith for their arduous attention to the child. We also thank the Medical Research Council for part-time grants.

\section{REFERENCES.}

1. Ambard. L. et al., Soc. méd. d. Hôp. de Paris, Paris, 1925, XLIX, 3s., 547.

․ Arndt, H. J.. \& Welcher, A., Ztschr. f. Kinderh., Berlin. 1926, XLI. 518.

3. Ashby, H., Lancet. London, 1923. i, 2-2.

4. Baumel, M. L., C.R. XIII cong. internat. de méd., Paris. 1999 (Sert. méd. de lenf.), 6:-7.

5. Bell, W. B., Edinb. Med. J., Edinb., 1896, XLI, 709.

6. Busch, Jahresb. u. d. Fortschr. d. Med.. Berlin. 1876, II. .27l ; cited by Stern, C. Arch f. Kinderh., Stuttgart, 1890, XI. 103.

7. Cuno, F., Ztschr. f. Kinderh., Berlin. Referate, 1912. i. 191.

8. De Lange, C., Am. J. Dis. Child., Chicago, 1926, XXI, 840.

9. Eaton, P. J., \& Woods, E. B., Tr. Am. Ped. Soc., Chic., 1911, XXIII, 244. 
10. Feldman, I., Centralbl. f. allg. Path. u. path. Anat., Jena, 1928. XLII. 435.

11. Garnerus, H., Deutsche med. Wchnschr., Leipsic, 1884, X, 697.

12. Hagenbach, Jahrb. $f$. Kinderh., Leipsic, 1879. XIII, 421.

13. Harrison, G. A., Dis. of Child., (Garrod, Batten, Thursfield \& Paterson). Lond., 19:9, 2nd Ed., $\mathbf{5 3 5}$.

14. Haüner, Wchnschr. f. d. ges. Heilkunde, Berlin, 1850, XXI, 321.

15. Heiberg, K. A., Arch. f. Kinderh., Stuttgart, 1911, LVI, 1911.

16. Hoet, J. P., \& Debois, G., Compt. rend. Soc. de Biol., Paris, 1930. CIII, j16.

17. Joslin, E. P., Treatm. of Diabetes Mell., Philad., 1928, 4th Ed., 838.

18. Joslin, E. P., Loc. cit., 148 \& 188.

19. Kitselle, J. f. Kinderh., Leipsic, 1852, XVIII, 313.

20. Knox, J. H. Y., Bull. Johns Hopkins Hosp., Baltimore, 1913, XXIV, 274.

21. Kochmann, R., Jahrb. f. Kinderh., Berlin, 1922, XCIX, 20.

22. La Barre, J., Arch. internat. de physiol., Liége, 1927, XXIX, 227.

23. La Barre, J., Compt. rend. soc. Biol., Paris, 19-28, XCIX, 1053.

24. Langstein, L., Verhandl. d. long. f. inn. Med., Wiesb., 1909, XXVI, 209.

25. Lauritzen, M., Arch. de méd. denf., Paris, 1910, XIII, 561.

26. Lenstrup, E., Klin. Wchnschr., Berlin, 1929, VIII, 2244.

27. Litchfield, H. R., \& Shermer, B., Ped. Bull., Baltimore, 1930, I, 5.

28. Major, R. H., \& Curran, E. J., J. Am. Med. Ass., Chicago, 1925, LXXXIV, 674.

29. Yorton, H. B., Nebraska Med. J., Lincoln, 1928, XIII, 9.

30. Nevinny, H., \& Schretter, G., Arch. f. Gymak., Berlin, 1930, CXL, 396 ; CXLIII, 46.5.

31. Nichues, F., cited by Wegeli, E., Arch. f. Kinderh., Stuttgart, 1896, XIX, 8.

32. Orloff, M. N., Abs. Semaine méd., Paris, 1901, XXI, 192.

33. Ramser, W. R., Tr. Am. Ped. Soc., Chicago, 1926, XXXVIII, 100.

34. Rosbach, T., Berl. Klin. Wchnschr., Berlin, 1874, II, 258.

35. Schippers, J. C., Am. J. Dis. Child., Chicago, 1925, XXX, 336.

36. Shelley, E. G., Pennsyliania Med. J., Harrisburg, 1931, XXXIV, 256.

37. Tavaria, H. K., Ind. Med. Chir. Rer., Bombay, 1893, I, 402.

38. Warren, S., Pathology of Diabetes Mell., Philad., 1930.

39. Young, W. E., Arch. Ped., N.Y., 1901, XVIII, 198. 